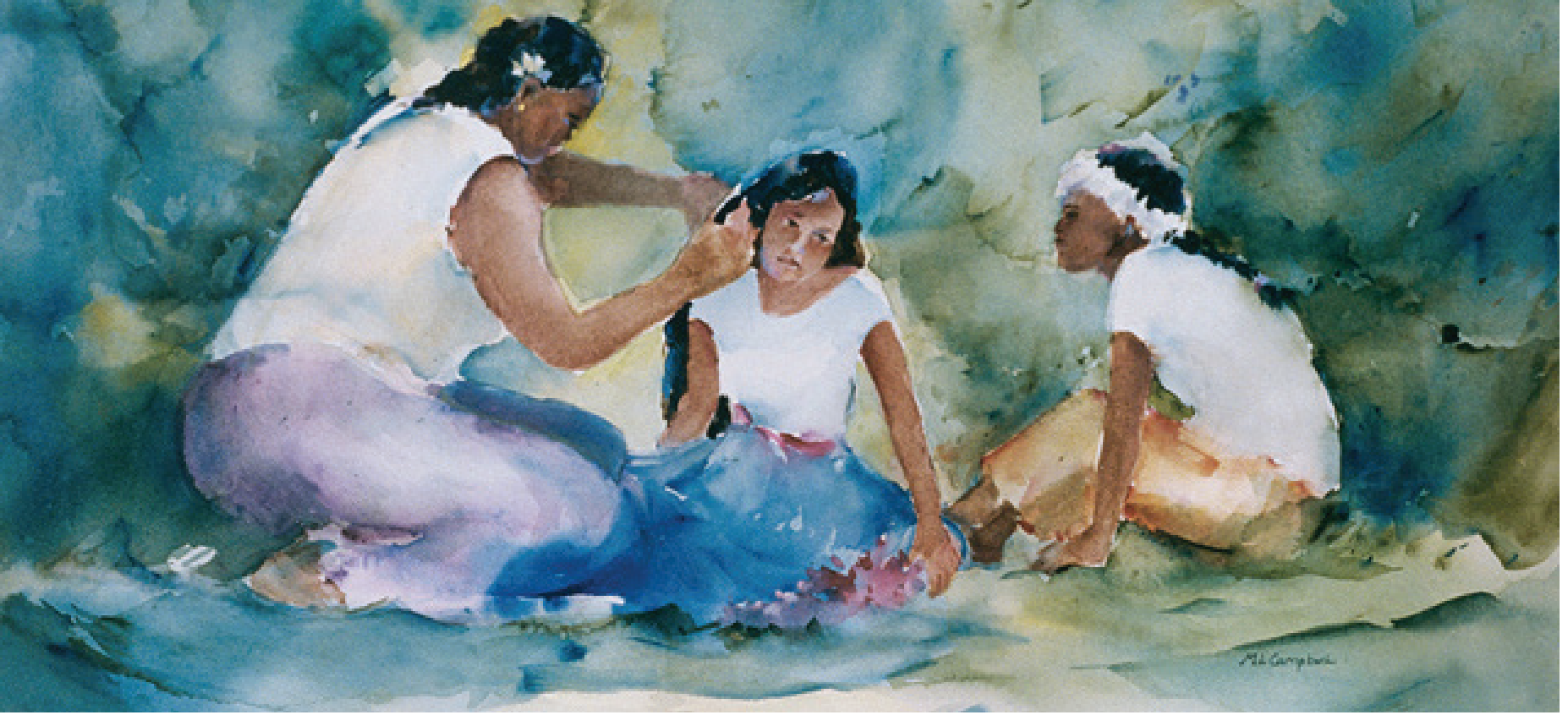

\title{
MENARCHE, PUBERTY AND VITAMIN D
}

\section{INTRODUCTION}

Recent findings, a number of epidemiologic studies and clinical trials claim that for normal growth and puberty sufficient levels of vitamin $D_{3}$ are important. Various studies investigate the role of vitamin $\mathrm{D}_{3}$ and its metabolites in specific reproductive disorders of women and men. It is known, that vitamin $\mathrm{D}_{3}$ modulates reproductive function in both women and men.

Vitamin $\mathrm{D}$ deficiency has been associated with chronic diseases, such as diabetes mellitus, certain types of cancer, neurologic disorders, cardiovascular risk, obesity and autoimmune diseases [1]. Nevertheless, data on the vitamin $D$ status and its association with puberty and its disorders in girls are constrained. This paper is aimed to investigate the link between vitamin $\mathrm{D}_{3}$ and puberty transition in girls. Vitamin $\mathrm{D}$ plays a key role in bone metabolism, maintaining of calcium homeostasis by intestinal and renal calcium absorption [1]. Majority of the effects of vitamin D are mediated by the vitamin $D$ receptor (VDR), which is the only protein that binds $1,25(\mathrm{OH})^{2} \mathrm{D}_{3}[1]$. The VDR is expressed in almost all body cells, such as immune cells, as well as ovary, testis, mammary gland, uterus, central nervous system cells and others [1]. All these data lead to extensive research on vitamin $D_{3}$ and its receptor as a potential influencing factor in the pathogenesis of a large number diseases, including infectious and autoimmune diseases, obesity, cancer, puberty disorders and infertility, connected with nonclassical function of this vitamin [1]. In the last few years, the prevalence of vitamin $D_{3}$ deficiency has increased in many parts of the world, what has caused an increasing number of medical research on the subject. Recent studies suggest that vitamin $D_{3}$ may be an important factor which triggers normal reproductive physiology. Unfortunately, the mechanisms by which vitamin $D_{3}$ deficiency affect female fertility and reproductive physiology are not yet well investigated properly.
There are few studies presenting the association of vitamin $D_{3}$ status and sexual maturation.

\section{VITAMIN D AND HYPOTHALAMIC-PITUITARY - GONADAL AXIS}

Puberty is the development process - the result of a complex series of molecular and physiological that culminates in reproductive capability. Puberty generally begins between the ages of 10 and 14 among girls. Boys undergo this period later, usually between 12 to 16 years of age. Gonadotropin-releasing hormone $(\mathrm{GnRH})$ actively released from specialized neurons of the hypothalamus initiates the hormonal cascade, which causes activation of gonads and in that way physical changes of puberty. Puberty depends upon well coordinated interactions among all components of the hypothalamic-pituitary-gonadal axis. There are several factors which have an influence on the activation of the hypothalamus to trigger puberty transition [2]. Dynamic changes in glialneuron interactions, and trans-synaptic changes in afferent gluttamatergic, kisspeptinergic and GABAergic neurons have influence on GnRH neurons [3]. These changes may induce sustained GnRh peptide release and activation of the pituitary-gonadal axis [4]. Cyp27b1 and VDR are highly expressed in the hypothalamus [5]. Except this, Cyp27b1 and VDR are found in the pituitary and gonads that suggests, that $1,25(\mathrm{OH}) \mathrm{D}_{3}$ may regulate the reproductive axis by its paracrine and/or autocrine activities on it [5]. Walker's and others research shows that vitamin $D_{3}$ receptor expression peaks in the hypothalamus during the peripubertal period in male rats, suggesting that central vitamin $D_{3}$ signaling may be important for pubertal transition [6]. Prepubertal vitamin $\mathrm{D}_{3}$ deficiency, in part, disrupts hypothalamic-pituitary function. Gezen-Ak and others suggested that vitamin $\mathrm{D}_{3}$ regulates expression of L-type voltage-sensitive calcium channels and nerve growth factor release in the brain [7]. It is possible that vitamin $D_{3}$ deficiency
E.F. CHAYKIVSKA associate professor of the Obstetrics,

Gynecology and Perinatology

Department of Postgraduate Education Faculty, Lviv National Medical University named after Danilo Galitsky, chief Pediatric and Adolescent Gynecologist in the Lviv region

Contacts:

Elina F. Chaykivska

Lviv National Medical University named after Danilo Galitsky,

Obstetrics, Gynecology and

Perinatology Department of Postgraduate Education Faculty George Washington street, 6 , Lviv, 79010

tel.: +380 (322) 701744 e-mail: e_chaykivska@mail.ru 
disrupts L-type voltage-sensitive calcium channel expression systems critical for peripubertal GnRH neuronal activation [8]. Studies in VDR null female mice suggest that vitamin $D_{3}$ deficiency induces gonadotropin-resistant atrophic ovaries [9].

There are several studies which show that girls with precocious puberty had insufficient levels of vitamin $\mathrm{D}_{3}$. Precocious puberty is diagnosed in girls when sexual development begins before the age of 8 , in boys, it is diagnosed when these changes occur before the age of 9 . Dicken and others in their study demonstrated another finding, which demonstrates that peripubertal vitamin $D_{3}$ deficiency delays puberty and causes prolonged estrous cycles in mice, which were characterized by extended periods of diestrus and reduced frequency of proestrus and estrus. Moreover, these estrous cycles could be normalized in young adults by correcting the vitamin $\mathrm{D}_{3}$ deficiency. According to these data Dicken and others suggested that peripubertal vitamin $D_{3}$ deficiency delays pubertal transition and disrupts estrous cyclicity by disrupting hypothalamic-pituitary axis physiology [4]. Therefore it is possible that vitamin $D_{3}$ directly regulates synthesis or release of gonadotropins and consequently regulates estrous cyclicity in mice. Even though, the relationship between vitamin $D_{3}$ deficiency and early puberty remains unclear.

\section{AGE OF MENARCHE AND VITAMIN D}

The first menstrual period, menarche, is one of the most significant milestones in a woman's life. The age at menarche is an important anthropological variant which may influence the overall duration of tissue oestrogen exposure and then affect woman's health in later life [10].

Age at menarche is known to be regulated by genetic and environmental factors [11]. The timing of menarche is genetically determined [12]. Early menarche is related to increased risk of adverse health outcomes during adulthood including obesity, type 2 diabetes, cardiovascular disease and breast and endometrial cancers $[13,14]$. In addition, early menarche has been associated with behavioral and psychosocial risk factors during adolescence, such as alcohol consumption and smoking, early sexual debut, and teenage pregnancy [15]. Modification of these factors might contribute to decreased risk of adverse health outcomes related to early menarche [16]. Grivas investigated that girls who lived at higher latitudes appeared to have earlier initiations of menses than girls who live closer to the equator [17]. Although it might be explained by differences in temperature, light-darkness rhythms, and socioeconomic conditions, it also corresponds with a geographic gradient in sun exposure that, in some regions, coincided with vitamin $D$ status [17]. Vitamin $D_{3}$ deficiency is associated with the development of adiposity in children and childhood obesity could be a risk factor for early puberty, thus, vitamin D might play a role in the timing of puberty [18]. Childhood obesity could lead

\section{REFERENCES}

1. Lee, H.S., Kim, Y.J., Shim, Y.S., Jeong, H.R., Kwon, E., Hwang, J.S.

"Associations between serum vitamin D levels and precocious puberty in girls." Ann Pediatr Endocrinol Metab, 19(2) (2014): 91-95.

2. DiVall, S.A., Radovick, S.

"Pubertal development and menarche." Ann NY Acad Sci, 1135(2008): 19-28.

3. Herbison, A.E., Moenter, S.M.

"Depolarising and hyperpolarising actions of GABA(A) receptor activation on gonadotropinreleasing hormone neuron requirements for puberty, ovulation, and fertility." Endocrinology, 149(2) (2008): 597-604. to accelerated sexual maturation [19]. The association between vitamin $D$ status and age at menarche could have been confounded by the age or adiposity level, because vitamin $\mathrm{D}$ could have been redistributed from blood into adipose tissue as a hydrophobic compound that's why and adiposity may have an independent risk factor for early menarche $[20,21]$. So this way, vitamin $D_{3}$ status could indirectly affect the age at menarche by its effect on obesity [22]. In cohort study of school-age girls, vitamin D deficiency was associated with the early onset of menses. The difference in the estimated mean age at menarche between vitamin D-sufficient and vitamin D-deficient girls in the research was almost 1 year [16]. Some studies in mice and humans indicated that increases in leptin resulted in early puberty [23]. $25(\mathrm{OH}) \mathrm{D}_{3}$ is inversely correlated with leptin concentrations. It is unknown that the expression of leptin or other hormones from adipose tissue would change in response to vitamin $D_{3}$ supplementation [16]. The other possible mechanism was that vitamin $D$ had inverse correlation with insulin-like growth factor-1 (IGF-1) [1]. IGF-1 modulates the onset of puberty and pubertal progression by stimulating the $\mathrm{GnRH}$ [1]. So, it is conceivable that vitamin D-mediated effects may influence IGF-1 levels and pubertal onset through an effect on gonadotropin and sex hormone [1]. Villamor and others followed a cohort of 242 healthy girls (age 5-12 years) for a median of 30 months and found that vitamin D deficient girls have an earlier initiation of menstruation than girls with sufficient vitamin $D_{3}[16]$. There could be other biological mechanisms involved in the association of vitamin $D$ deficiency with early menarche that are independent of obesity. Early menarche and vitamin D deficiency are both associated with poor health outcomes, and further exploration of their association is important for women's health [2].

\section{CONCLUSION}

In conclusion, this paper was written to show different studies on vitamin $D_{3}$ and its influence on puberty. Consequently, vitamin $D_{3}$ deficiency was more common in girls with central precocious puberty than girls with normal sexual maturation. Although the mechanism of vitamin $D$ deficiency's effect on pubertal progression is unclear and not yet well understood. We suggest that vitamin $D_{3}$ may regulate sexual maturation in girls. In the recent years emerging data have suggested that vitamin $D_{3}$ is not only important for the maintenance of bone health and for calcium and phosphate homeostasis, but also has an influence on neurohormonal regulatory multisystem effects, that can modulate health outcomes in women. Nevertheless, a lot of investigations suggest that an individual's vitamin $D_{3}$ status may adversely impact reproductive functions. A key to the normal physiological initiation of puberty process is a proper administration of vitamin $D_{3}$ supplementation which could be an effective strategy to improve reproductive health in the group of adolescent girls.

\footnotetext{
4. Dicken, C.L., Israel, D.D., Davis, J.B., Sun, Y., Shu, J., Hardin, J., Neal-Perry, G. "Peripubertal vitamin $D_{3}$ deficiency delays puberty and disrupts the estrous cycle in adult female mice." Biol of Reprod, 87(2) (2012): 51.

5. Eyles, D.W., Smith, S., Kinobe, R., Hewison, M., McGrath, J.J.

"Distribution of the vitamin D receptor and 1 alpha-hydroxylase in human brain." J Chem Neuroanat, 29(1) (2005): 21-30.

6. Walker, D.M., Juenger, T.E., Gore, A.C

"Developmental profiles of neuroendocrine gene expression in the preoptic area of male rats." Endocrinology, 150(5) (2009): 2308-2316.
} 
7. Gezen-Ak, D., Dursun, E., Yilmazer, S.

"The effects of vitamin D receptor silecing on the expression of LVSCC-A1C and the release of NGF in cortical neurons." PLoS One, 6(3) (2011): e17553.

8. Malinina, E., Druzin, M., Johansson, $S$.

"Differential control of spontaneous and evoked GABA release by presynaptic L-type Ca2+ channel in the rat medial preoptic nucleus."J Neurophysiol, 104(1) (2010): 200-209.

9. Kinuta, K., Tanaka, H., Moriwake, T., Aya, K., Kato, S., Seino, Y.

"Vitamin $D$ is an important factor in estrogen biosynthesis of both female and male gonads." Endocrinology, 141(4) (2000): 1317-1324.

10. Long, J.-R., Xu, H., Zhao, L.-J., Liu, P.-Y., Shen, H., Liu, Y.-J., Xiong, D.-H., Xiao, P., Liu, Y.-Z., Dvornyk, V., Li, J.-L., Recker, R. R., Deng, H.-W.

"The oestrogen receptor a gene is linked and/or associated with age of menarche in different ethnic groups."J Med Genet, 42(2005): 796-800.

11. Ku, S.Y., Kang, J.W., Kim, H., Kim, Y.D., Jee, B.C., Suh, C.S., Choi, Y.M., Kim, J.G., Moon, S.Y., Kim, S.H.

"Age at menarche and its influencing factors in North Korean female refugees." Hum Reprod, 2(3) (2006): 883-886.

12. Elks, C.E., Perry, J.R., Sulem, P., Chasman, D.I., Franceschini, N., He, C., Lunetta, K.L., Visser, J.A., Byrne, E.M., Cousminer, D.L.

"Thirty new loci for age at menarche identified by a meta-analysis of genome-wide associations studies." Nat Genet, 42(2010): 1077-1085.

13. He, C., Zhang, C., Hunter, D.J., Hankinson, S.E., Buck-Louis, G.M., Hediger, M.L., Hu, F.B. "Age at menarche and risk of type 2 diabetes: results from 2 large prospective cohort studies." Am J Epidemiol, 171(2010): 334-344.

14. Dossus, L., Allen, N., Kaaks, R., Bakken, K., Lund, E., Tjonneland, A., Olsen, A., Overvad, K., Clavel-Chapelon, F., Fournier, A.

"Reproductive risk factors and endometrial cancer: the European Prospective Investigation into Cancer and Nutrition." Int J Cancer, 127(2010): 442-451.

15. Golub, M.S., Collman, G.W., Foster, P.M., Kimmel, C.A., Rajpert-De Meyts, E., Reiter, E.O., Sharpe, R.M., Skakkebaek, N.E., Toppari, J.
"Public health implications of altered puberty timing." Pediatrics, 121(3) (2008): 218-230.

16. Villamor, E., Marin, C., Mora-Plazas, M., Baylin, A.

"Vitamin D deficiency and age at menarche: a prospective study." Am J Clin Nutr, 94(2011): 1020-1025.

17. Grivas, T.B., Vasiliadis, E., Mouzakis, V., Mihas, C., Koufopoulos, G.

"Association between adolescent idiopathic scoliosis prevalence and age at menarche in different geographic latitudes." Scoliosis, 1(2006): 9.

18. Gilbert-Diamond, D., Baylin, A., Mora-Plazaz, M., Marin, C., Arsenault, J.E., Hughes, M.D., Willett, W.C., Villamor, E.

"Vitamin D deficiencyand banthropometric indicators of adiposity in school-age children: a prospective study." Am J Clin Nutr, 92(2010): 1446-1451.

19. Davison, K.K., Susman, E.J., Birch, L.L.

"Percent Body fat at age 5 predicts earlier pubertal development among girls at age 9." Pediatrics, 111(2003): 815-821.

20. Lee, J.M., Appugliese, D., Kacirioti, N., Corwyn, R.F., Bradley, G.H., Lumeng, J.C.

"Weight status in young girls and the onset of puberty." Pediatrics, 119(2007): 624-630.

21. Martini, L.A., Wood, R.J.

"Vitamin D status and the metabolic syndrome." Nutr Rev, 64(2006): 479-486.

22. Chew, A., Harris, S.S.

"Does vitamin D affect timing of menarche?" Nutr Rev, 71(3) (2013): 189-193.

23. Donoso, M.A., Munoz-Calvo, M.T., Barrios, V., Garrido, G., Hawkins, F., Argente, J.

"Increased circulating adiponectin levels and decreased leptin/soluble leptin receptor ratio throughout puberty in female ballet dancers: association with body composition and the delay in puberty." Eur J Endocrinol, 162(2010): 905-911.

24. Gutiérrez-Medina, S., Gavela-Pérez, T., Domínguez-Garrido, M.N., Gutiérrez-Moreno, E., Rovira, A., Garcés, C., Soriano-Guillén, L.

"The influence of puberty on vitamin D status in obese children and the possible relation between vitamin D deficiency and insulin resistance."J Pediatr Endocrinol Metab, 10(2014): 1515.

\section{MENARCHE, PUBERTY AND VITAMIN D}

E.F. Chaykivska, associate professor of the Obstetrics, Gynecology and Perinatology Department of Postgraduate Education Faculty, Lviv National Medical University named after Danilo Galitsky, chief Pediatric and Adolescent Gynecologist in the Lviv region

Puberty is the development process - result of a complex series of molecular and physiological events, culminating in reproductive capability. Gonadotropin-releasing hormone actively released from specialized neurons of the hypothalamus stimulates gonadal activation and triggers physical changes of puberty through initiation of the hormonal cascade. Epidemiologic studies and numerous clinical trials claim that sufficient levels of vitamin $\mathrm{D}_{3}$ are essential for normal physiological growth, development and puberty, by activation of the neurohormonal multisystem in the hypothalamus-pituitary-gonadal axis. Various scientific studies investigate the role of vitamin $\mathrm{D}_{3}$ and its metabolites in specific reproductive disorders of women and men. All these data contribute to intensive research on vitamin $D_{3}$ and its receptor as a potential factor, affecting the pathogenesis of a numerous diseases, connected with its non-classical function, such as diabetes, obesity, cancer, puberty disorders and infertility. In the last decade, the prevalence of vitamin $\mathrm{D}_{3}$ deficiency has been increasing in many parts of the world, that has caused an increasing number of medical research on the subject. Nevertheless, data on the vitamin D status and its association with puberty in girls are constrained. This paper was written to present different studies on vitamin $D_{3}$ and its influence on puberty through the regulation of the neurohormonal system during sexual maturity.

Keywords: menarche, vitamin $\mathrm{D}_{3}$, puberty, precocious puberty.

\section{MEHAPXE, ПУБЕРТАT I ВІTАMIH D}

Е.Ф. Чайківська, доцент кафедри акушерства, гінекології і перинатології факультету післядипломної освіти ЛНМУ ім. Данила Галицького, головний позаштатний спеціаліст з дитячої та підліткової гінекології Львівської області

Статеве дозрівання - це процес, що відбувається в результаті складної серії молекулярнихі фізіологічних явищ, кульмінацієєо якого єздатність організму до репродукції. Активне виділення гонадоліберину із спеціалізованих нейронів гіпоталамуса започатковує каскад гормональних процесів, які, в свою чергу, призводять до активації гонад і тим самим дають поштовх анатомофізіологічним змінам організму в період пубертату. Епідеміологічні дані та численні клінічні дослідження вказують на те, що відповідний рівень вітаміну $\mathrm{D}_{3}$ має велике значення для нормального фізіологічного росту, розвиткуі статевого дозрівання, діючи шляхом активації нейрогормональної мультисистеми в гіпоталамо-гіпофізарно-гонадній осі. Останні дослідження вивчають роль вітаміну $\mathrm{D}_{3}$ і його метаболітів в конкретних порушеннях репродуктивного здоров'я жінокі чоловіків. Дослідження вітаміну $\mathrm{D}_{3}$ і його рецептора довели його потенційний вплив на патогенез численних захворювань, не пов'язаних із класичною дією вітаміну $\mathrm{D}_{3}$ - таких як цукровий діабет, ожиріння, рак та інші. Чисельність осіб із дефіцитом вітаміну $\mathrm{D}_{3}$ в багатьох частинах світу в останні кілька років зросла, через що активізувалися медичні дослідження з ціёі теми. Проте дані про вплив вітаміну $\mathrm{D}_{3}$ на процес статевого дозрівання у дівчаток залишаються недостатньо вивченими. Дана стаття представляє ряд світових досліджень, що описують вплив вітаміну $\mathrm{D}_{3}$ на регуляцію нейрогормональної системи в період статевого дозрівання.

Ключові слова: менархе, вітамін $\mathrm{D}_{3^{\prime}}$ пубертат, передчасний статевий розвиток.

\section{МЕНАРХЕ, ПУБЕРТАТ И ВИТАМИН D}

э.Ф. Чайкивска, доцент кафедры акушерства, гинекологии и перинатологии факультета последипломного образования ЛНМУ им. Данила Галицкого, главный внештатный специалист по детской и подростковой гинекологии Львовской области

Половое созревание - это процесс, осуществляющийся в результате сложной серии молекулярных и физиологических явлений, кульминацией которого является способность организма к репродукции. Активное выделение гонадолиберина из специализированных нейронов гипоталамуса начинает каскад гормональных процессов, которые, в свою очередь, приводят к активации гонад и тем самым дают толчок анатомо-физиологическим изменениям организма в период пубертата. Эпидемиологические данные и многочисленные клинические исследования указывают на то, что соответствующий уровень витамина $\mathrm{D}_{3}$ имеет большое значение для нормального физиологического роста, развития и полового созревания, действуя путем активации нейрогормональной мультисистемы в гипоталамо-гипофизарно-гонадной оси. Последние исследования изучают роль витамина $\mathrm{D}_{3}$ и его метаболитов в конкретных нарушениях репродуктивного здоровья женщин и мужчин. Исследование витамина $\mathrm{D}_{3}$ и его рецептора доказали его потенциальное влияние на патогенез многочисленных заболеваний, связанных с классическим действием витамина $\mathrm{D}_{3}$ - таких как сахарный диабет, ожирение, рак и другие. Численность лиц с дефицитом витамина $\mathrm{D}_{3}$ во многих странах мира в последние несколько лет увеличилась, вследствие чего активизировались медицинские исследования по этой теме. Тем не менее, данные о влиянии витамина $\mathrm{D}_{3}$ на процесс полового созревания у девочек остаются недостаточно изученными. Данная статья представляет ряд мировых исследований, описывающих влияние витамина $\mathrm{D}$, на регуляцию нейрогормональной системы в период полового созревания.

Ключевые слова: менархе, витамин $\mathrm{D}_{3^{\prime}}$ пубертат, преждевременное половое развитие. 